\title{
The Effects of Various LED Light Wavelengths to the Physiological and Morphological Parameters of Stevia (Stevia rebaudiana) Bertoni
}

\author{
Esra UCAR ${ }^{1 *}$, Nuri CAGLAYAN ${ }^{2}$, Kenan TURGUT ${ }^{3}$ \\ ${ }^{1}$ Cumburiyet University, SivasVocational School,Department of Medicinal and Aromatic Plants, Sivas, Turkey; eucar@cumburiyet.edu.tr(*correspondingauthor) \\ ${ }^{2}$ Akdeniz University, Faculty of Engineering, Department of Mechatronics Engineering, Antalya, Turkey; nuricaglayan@akdeniz.edu.tr \\ 3Akdeniz University, Faculty of Agriculture,Department of Field Crops, Antalya, Turkey; kturgut@akdeniz.edu.tr
}

\begin{abstract}
In this study, it was investigated the growth of stevia (Stevia rebaudiana Bertoni) under various wavelengths of LED lamp (Light Emitting Diodes), which can emit daylight (cool white; 400-700 nm), red (620-630 nm) and blue (465-485 nm) wavelengths of the light in the electromagnetic spectrum. In all applications, quantity of PAR (photosynthetically active radiation) was adjusted as $150 \mu \mathrm{mol} . \mathrm{m}^{-2} \mathrm{~s}^{-1}$. Study had maintained in plant breeding cabin 16 hours light and 8 hours dark environment. Results demonstrated that while the highest plant height was determined in the " $30 \%$ blue light $+70 \%$ red light" application, the highest stem length was found in the " $50 \%$ blue light + $50 \%$ red light" application. In addition, the number of the stems reached the highest value in the "70\% blue light $+30 \%$ red light" application. Consequently, a correlation was observed between negative " $a$ " value and the amount of chlorophyll. Because of the hereby obtained results, comparing to other applications, the " $50 \%$ blue light $+50 \%$ red light" was found as the best light application to obtain optimum yield values of stevia.
\end{abstract}

Keywords: blue light, stevia, light-emitting diodes, red light, PAR

\section{Introduction}

Stevia (Stevia rebaudiana Bertoni) is a perennial plant from Asteraceae family. Stevia has nearly 230 species as herbaceous, bush and half bush (Cimpeanu et al., 2006; Yadav et al., 2011). Because this plant includes steviol glycosides, it is used commercially in many countries with the purpose of sweeting and flavorant instead of synthetic sweetings. The leaves of stevia include glycosides of dulcoside-A, rebaudiosides A, B, C, D, E, stevioside that are sweeter than sucrose (Carneiro et al., 1997). The dry leaves of this plant are 15-20 times sweeter than sugar and also powder extracts of this plant are 300 times sweeter than sugar and it is zero calories (Singh and Rao, 2005). So, diabetics and dieters (Fronza and Folegatti, 2003) can conveniently consume stevia. Stevia has diuretic, analgesic and blood pressure-lowering characteristics and it can be used for stomach ache with the purpose of herbal treatment (Argueta and Cano, 1993). Moreover, it has important biological activities such as antimicrobial and antifungal properties (Cerda-García-Rojas and Pereda-Miranda, 2002) and it has antioxidant effects (Okawa et al., 2001). The research on rats has been shown that stevia has no side effect and its usage has been recommended to diabetics (Megeji et al., 2005). Because of these prominent properties, the production and trading of stevia are desired in many countries. Therefore, stevia is produced commonly in Paraguay, Brazil, Mexico, Uruguay, Guatemala, Peru, Japan, South Korea (Inanç and Cınar, 2009).
In terms of cultivation, this plant has been grown better in the regions, which have sufficient moisture and well drainage clayey, alluvial or red soils and $1500-1800 \mathrm{~mm}$ rainfall per year with $25^{\circ} \mathrm{C}$ average temperature (Shock 1982; Singh and Rao, 2005). With greenhouse farming, small areas are made useful in order to take high efficiency from unit area without depending on climatic conditions (Sevgican et al., 2000). However, light is critically important, in order to get a good efficiency from plants, because light energy is needed for photosynthesis and producing organic matter via using inorganic matters (water, carbon dioxide) and chlorophyll (Anonym, 2015). The quality of light has important effect on morphological characteristics of plants such as lengthening of plants, stem forms, leaf anatomies and leaf sizes (Yağcioğlu, 1996). Especially in greenhouse farming, the amount of light may not be enough for sufficiently growth and flourishing of plants, therefore, most times it is necessary to make photoperiodic illumination and provide the lack photosynthetic active radiation (PAR) energy with synthetic light sources. Photoperiodic illumination provides artificially organizing of illuminated time in order to control the plant growth (Çăglayan and Ertekin, 2011). Red lights is major important for plant growth because it induces transformations in photochrome system of plants (Furuya, 1993). Blue light is necessary for plants because it is effective on consisting of chlorophyll, opening of stomas and photomorphogenesis (Urbonaviciute et al., 2007).

In photoperiodic illumination, if high dose red light and blue light is given together, it incites blooming and seed 
production. Blue light is responsible for vegetative growth and it supplies the morphologically healthful of the plant. Chlorophyll that exists in the green leaves of the plant affects the photosynthesis ability and speed. In artificial illuminations for agricultural purpose, LED lamps are more preferred because they can emit a specific wavelength of light. The AllGaP based and powerful LEDs are able to emit $660 \mathrm{~nm}$ wavelength of light and this wavelength is important because it is near to 640 $\mathrm{nm}$ wavelength, which is important for plants. So, the PAR energy, which is necessary for plants, is utilized more efficiently (Koç et al., 2009; Çağlayan and Ertekin, 2011). In this research, the physiological and morphological differences of stevia, which was grown under various wavelengths of LED light, were examined. Therefore, this study goal is to determinate the most appropriate wavelengths of light, in order to increase the stevia yield.

\section{Materials and Methods}

Experiments have been performed in 252-Liter capacity climatic controlled plant cultivation cabin (Nuve, TK252) located in Akdeniz University Faculty of Agricultural, Agricultural Machinery and Technologies artificial illumination laboratory in 2013 March-November (Fig. 1). LED lamp is designed specially for cabin and it consists of Power LED belongs to CREE firm XLamp XP-C high flux (1W, $350 \mathrm{~mA}$ ). The lamp can emit daylight (cold white; $400-700 \mathrm{~nm} ; 6500 \mathrm{~K}$ ), red $(620-630 \mathrm{~nm})$ and blue $(465-485 \mathrm{~nm})$ wavelengths of the light (Fig. 2).

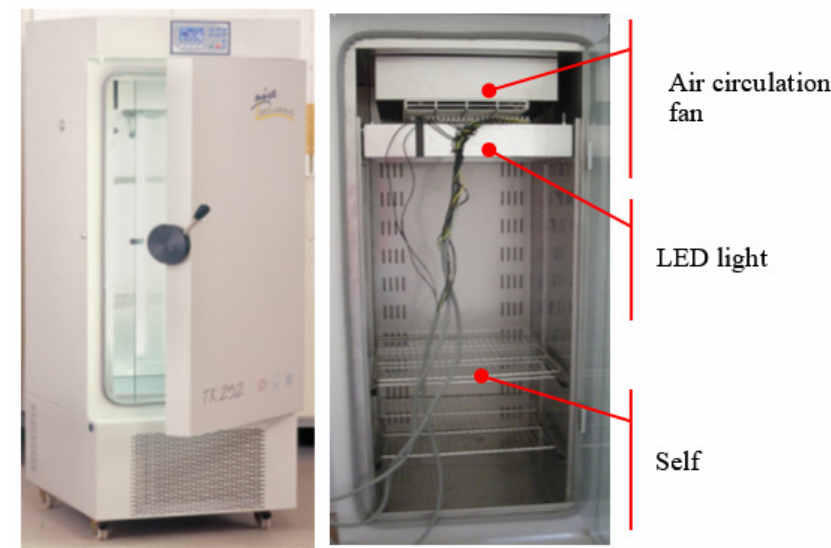

Fig. 1. Plant cultivation cabinet (Nüve, TK252)

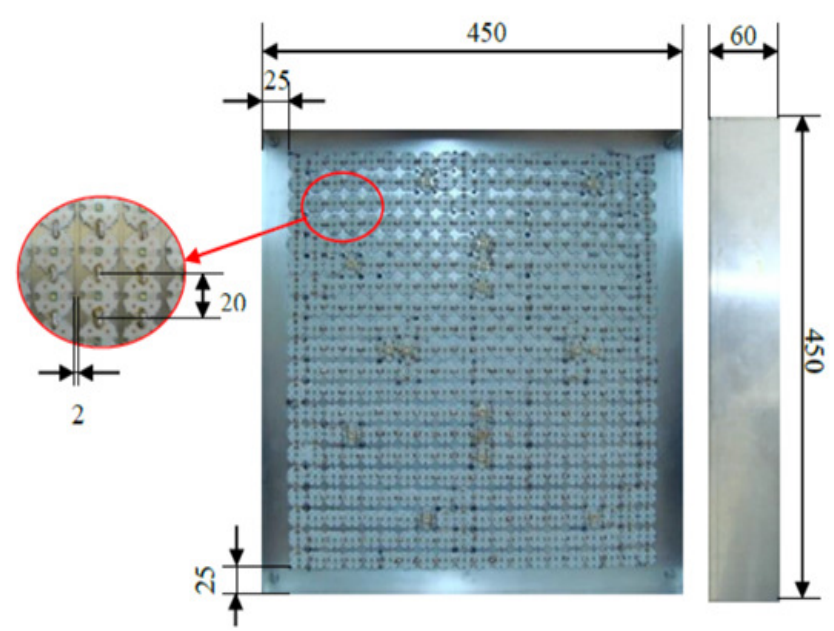

Fig. 2. LED lamp
In the research, four light types were used as " $50 \%$ blue + $50 \%$ red light"; " $70 \%$ blue $+30 \%$ red light"; " $30 \%$ blue $+70 \%$ red light" and daylight and lighting experiments, which each one lasts 60 days were performed. In each day, 16 hours light and 8 hours dark applications were carried out. The total PAR quantity of red light and blue light was kept constant at 150 umol. $\mathrm{m}^{-2} . \mathrm{s}^{-1}$. Cabin interior environment, air temperature and relative humidity values were arranged as $22{ }^{\circ} \mathrm{C}, 70 \%$ during illuminated time and $18{ }^{\circ} \mathrm{C}, 75 \%$ during dark time respectively. PAR quantum sensor (LI-190, LI-COR Inc.), has been used for measurements of PAR values and a data logger (DL2e, Delta-T Devices) has been used for recording PAR temperature and humidity values.

At the beginning of the study, seeds were taken from stevia seedlings cultivated in open field and these were germinated in viols. After one week, the seeds were germinated and they were transported to climate-controlled growth cabin. Experiments were conducted as a randomized complete design method with three replicates and five plants were used for each application, according to experimental design. Seeds were sowed to viols as for that totally fifteen plants for each viol.

Each application lasted 60 days and after the application and for each plant, the amounts of chlorophyll L, $a, b$ values, stem and root lengths, the number of leaf and the thickness of plant were measured. The obtained data were analyzed by appropriate analysis of variance and Duncan grouping method was performed whether there was a relationship between the different light applications. MSTAT-C software was used for performing of analysis (Freed, 1988).

For determining the chlorophyll amount, measurements were performed from each leaf with a chlorophyll meter (SPAD 502) for three times and average values were calculated (Zhu et al., 2012). In determining color changes in leaves of plant, leaf samples were taken randomly from all plants and these samples were measured by using a chroma meter (Minolta CR-200) as CIE $\mathrm{L}, a, b$. The value of $\mathrm{L}$ expresses the brightness and takes different values between 0 and 100 . Upon the value of $\mathrm{L}$ is 0 , which means black color, there is not any reverberation and when it takes 100, it means white color that has perfect reverberation (Fig. 3). On the other hand, positive " $a$ " value represents red color and negative " $a$ " represents green color. While positive " $b$ " values present yellow color, the negative " $b$ " values represent blue color. At the point of zero-cut $(a=0$ and $b=0$ ), it becomes colorless or grey (Fig. 4). Chroma $\left(\mathrm{C}^{*}\right)$ and hue angle $\left(h^{*}\right)$ values have been calculated by using equations below (McGuire 1992):

$$
\begin{aligned}
C^{*} & =\sqrt{ }\left(a^{*}\right)^{2}+\left(b^{*}\right)^{2} \\
h^{\circ} & \left.=\tan ^{-1}\left(a^{*} / b^{*}\right)\right]
\end{aligned}
$$

\section{Results and Discussion}

\section{Chlorophyll amounts of leaves}

The chlorophyll quantity existing in leaf is one of the factors that affect the photosynthesis speed and it is a significant indicator used for measuring the growth of chloroplast, photosynthetic capacity, content of leaf nitrogen and general vitality of plant ( $\mathrm{Yol}$ and Uzun, 2011). During light reaction, light is absorbed by chlorophyll pigment and induced an electron transport (Jao and Fang, 2003). In this research, a chlorophyll meter (SPAD 502, Spectrum Technologies, Inc.) was used for determining the chlorophyll quantity in plant samples. 
356

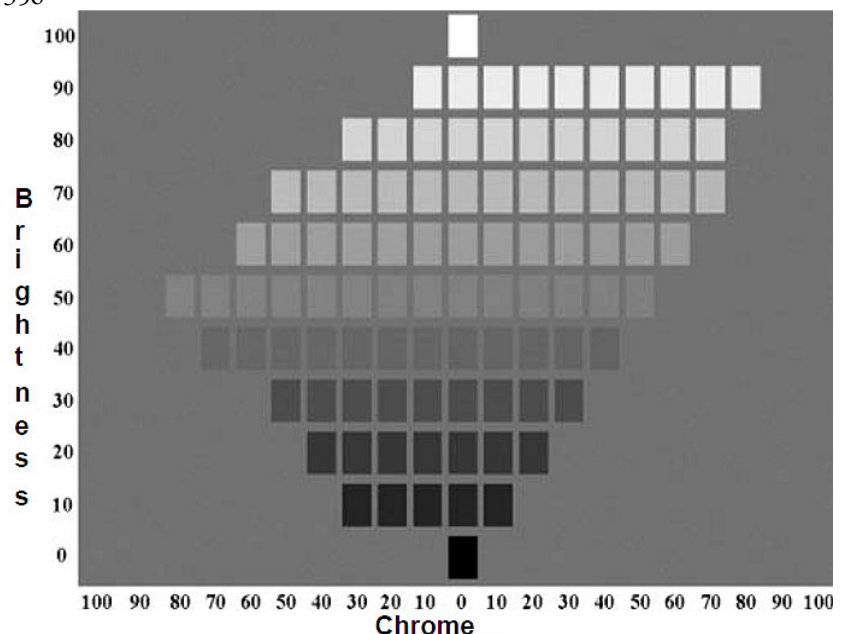

Fig. 3. Brightness - chrome diagram

According to obtained results, the plants applied the blue light, red light and daylight have statistically significant ( $P$ $\leq 0.05$ ) effects on chlorophyll amounts (Table 1). Hence, the maximum chlorophyll amount was acquired in " $50 \%$ blue light $+50 \%$ red light" application (39.08) and " $70 \%$ blue $+30 \%$ red light" and "30\% blue $+70 \%$ red light" applications respectively follow it. Chlorophyll molecules absorb the blue $(460-480 \mathrm{~nm})$ and red $(650-700 \mathrm{~nm})$ radiations better and these wavelengths are more effective on plant growth (Yeh and Chung, 2009). Therefore, the minimum chlorophyll amount (32.44) was determined in plants cultivated under daylight. In a study on tomatoes (Çağlayan and Ertekin, 2011), while the maximum chlorophyll amount was obtained in seedlings under MHL (Metallic Halide Lamp) light, the nearest measurement to this value was determined in the " $10 \%$ UV-A $+10 \%$ red light $+70 \%$ blue light" light application. In another study, the effect of red LED light on chlorophyll synthesis was emphasized (Tripathy and Brown, 1995). While in a study carried out by Brazaityte et al. (2010), decreasing was observed in chlorophyll amount with the orange ( $622 \mathrm{~nm})$, yellow $(595 \mathrm{~nm})$, green $(520 \mathrm{~nm})$ and $\mathrm{UV}(380 \mathrm{~nm})$ light applications on tomatoes, in an another study in which was used the same lights and same plant, the highest chlorophyll content was determined under yellow light $(595 \mathrm{~nm})$ (Brazaityte et al., 2010). In addition, when Jao et al. (2005) compared LED applications, the blue light mainly took the chlorophyll growth control mechanism task. According to $\mathrm{Wu}$ et al. (2011), the highest SPAD value was obtained with "70\% red light $+30 \%$ blue light" application on strawberry plant.

\section{$L, a, b$ values of leaves}

When the PAR that is active radiation area for photosynthesis is considered, it is observed that light is a factor that affects the photosynthesis speed of plants. Upon the blue and red lights are removed from environment, life of plants stops and death occurs. Furthermore, the amounts of red light and blue light change depending on the incidence angle of solar lights to the earth and seasons. According to Seeman (1952), when solar lights come to the earth with 10-16 degree angles, the

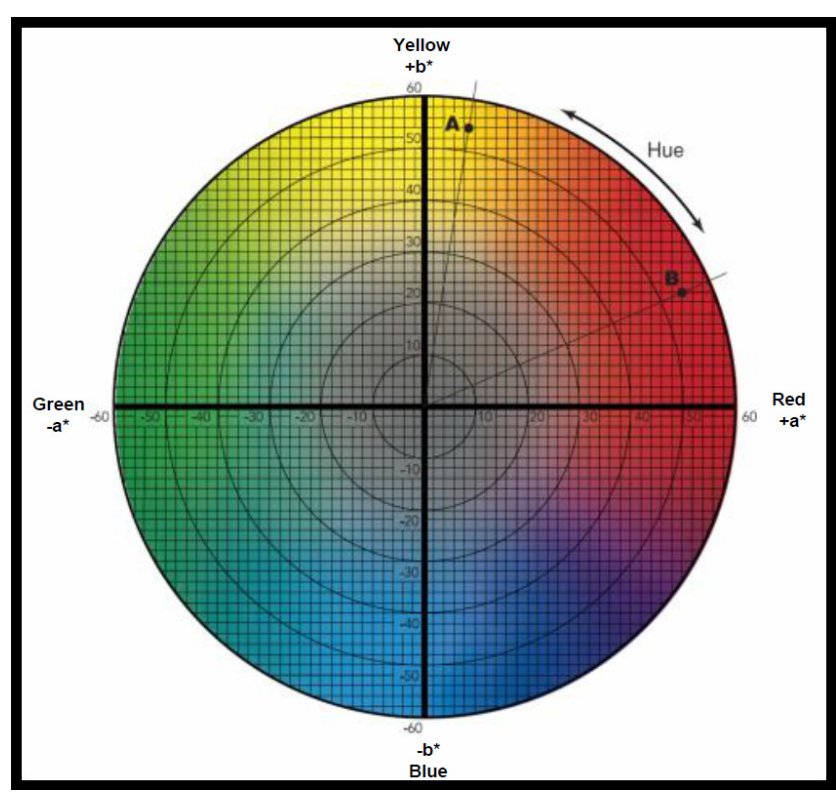

Fig. 4. Colour diagram

amount of red light is twice more than the amount of blue light. Because incidence angle of solar lights increases in summer months, the amount of blue light increases. On the other hand, owing to decreasing of incidence angle in the winter, the amount of red light increases. Sometimes, insufficient blue light can causes to yellowed leaves $\mathrm{Mc}$ Cree, 1972; Çağlayan and Ertekin, 2011). In addition, the color differences are observed in plant leaves indifferent periods depending on the seasonal or nutrient content changes. In our study, on behalf of these different wavelengths of the light, the color parameters of plant leaf were measured with color spectrophotometer and the effects of light applications on negative " $a$ " and positive " $b$ " values (respectively $\mathrm{P} \geq 0.01$ and $\mathrm{P} \geq 0.05$ ) were regarded as statistically significant.

In obtained findings, while the " $a$ " value representing green color decreases, green color of leaves increases and the highest " $a$ " values were obtained in " $50 \%$ blue $+50 \%$ red light" application (18.51) and the lowest " $a$ " values were obtained in daylight application (15.46). According to Öztürk (2008), blue light caused the darker green leaves. Furthermore, because the plants grown under red LED had less chlorophyll and photosynthesis ratio, yellowing was observed in their leaves. Nevertheless, according to some reports, a normal plant growth can be observed even just under red light without blue light depending on plant type (Nhut and Nam, 2010). As for our study, very low chlorophyll amount was determined in intense red light application and the negative " $a$ " value representing the chlorophyll quantity in leaf and green color of leaf was obtained in same application. Therefore, there is also a strong relationship between negative " $a$ " values and chlorophyll content of stevia. Hence, it was determined that the leaf chlorophyll content and color changings of stevia showed a parallel alteration depending on the amount of light that applied to plant. In another study, there is a strong relationship between leaves " $a$ " color values and chlorophyll contents (Demirtaş and Kirnak, 2009). Furthermore, upon positive " $b$ " values 
representing yellow color were evaluated, while the highest " $b$ " value was obtained in white light application (24.77), it was not observed a significant difference between white light and " $50 \%$ blue light $+50 \%$ red light" application (23.88). Additionally the lowest " $b$ " value was determined in "70\% blue + 30\% red light" application (21.40). Therefore, according to these obtained data, light applications in different wavelengths had a significant effect on leaf color of stevia plant.

The " $L$ " value represents brightness of plant leaf for $L$, $\mathrm{a}, \mathrm{b}$ measurements. According to our results, the different light applications had a statistically significance $(\mathrm{P} \leq 0.01)$ on " $L$ " values (Table 1 ). Hence, the highest " $L$ " value was obtained from " $70 \%$ blue light $+30 \%$ red light" application (44.50) and "50\% blue $+50 \%$ red light" and daylight applications followed this respectively. On the other hand, the lowest " $L$ " value was determined in " $30 \%$ blue $+70 \%$ red light" application (40.34). In other words, at the end of the 60 daily lighting experiment, it is determined that " $70 \%$ blue $+30 \%$ red light" application, which has intense blue light, generates more bright leaves than other applications.

\section{Growth parameters}

Growth, yield and quality of plants are not directed just by genetic factors. Light is also one of the environment factors that necessary for photosynthesis and growing of plant just like plant nutrition elements, quality of water and temperature. These factors are among the delimiting or enhancing factors of plant growth. Light is the elementary energy source for photosynthesis (Yağcioğlu, 1996) and plants need to sufficient light for growth. Increase in light intensity, which is in certain limits and ratios, speeds up growing in plants. In addition, it has a significant impact on determining of some morphological characteristics such as lengthening of plants, root shape and leaf anatomy (Vardar, 1975; Heuvelink, 1989; Uzun, 1996; Kevseroğlu, 1999; Aybak, 2002). In addition, photosynthesis reaches the highest speed in the blue and red regions of the electromagnetic spectrum (Öztürk, 2008).

According to statistically analysis of obtained data, in various wavelengths of light applications have statistically importance on the plant height, the number of root and the root lengths. While the longest plant height was obtained in " $30 \%$ blue $+70 \%$ red light" application (13.6), the shortest plant height was determined in " $50 \%$ blue + $50 \%$ red light" application (8.04). Generally, while the cold colors (e.g. blue, $460-480 \mathrm{~nm})$ cause to short plants, the hot colors (e.g. red, 650-700 nm) incite the elongation of plants (Çağlayan and Ertekin, 2011). Red light is effective on stem elongation of plant, leaf growth and chlorophyll synthesis (Tripathy and Brown, 1995) but it can cause to decrease in chlorophyll content of leaf (Nhut and Nam, 2010). When the plants that include extremely high chlorophyll are compared, the plants that include less chlorophyll use chlorophyll more efficiently (Saebo $e t$ al., 1995). As for our study, less chlorophyll ratio (35.92) was determined in " $30 \%$ blue $+70 \%$ red light" application, which had more intense red light compared to applications that had more intense blue light. In this application, the longest plant height was also obtained.

There are indirect or direct effects of light intensity, light type and light influence time on plant growth. Both red light and blue light incite the cell elongation in plant stem and leaves. Moreover, photosynthesis ratio and dry matter production increase (Matsuda et al., 2004; Spalding and Folta, 2005). According to Jao and Fang (2004), irradiation of the plants with red and blue lights at the same time had positively effects on plant growth. The responses of plants to blue and red LED ratios change depending on their species (Nhut and Nam, 2010). Çağlayan and Ertekin (2011) reported that under more intense blue light applications, they obtained short seedlings but had thicker stems. According to Brazaityte et al. (2010), while the red, blue and UV lights positively affected the growth of tomatoes. Wu et al. (2011) has reported the maximum plant dry weight in strawberry under "70\% red and 30\% blue light" application. While Piszczek and Glowacka (2008) observed the maximum height in cucumber under the blue light application, Jao et al. (2005) determined the longest plants under the red LED light for black magic.

In our study, the different wavelengths of light showed significant effects on root lengths of stevia. Therefore, while the maximum root length was observed under " $50 \%$ blue $+50 \%$ red light" application as $16.44 \mathrm{~cm}$, the minimum root length was determined under daylight application as $13.20 \mathrm{~cm}$. It is most probably, the low red light ratio obstructs growth of roots of stevia, because red light positively affects the root growth of plant (McCree, 1972; Çağlayan and Ertekin, 2011). On the other hand, while maximum number of root was obtained under " $70 \%$ blue and 30\% red light" application (7.8), minimum number of root was observed under red light and "30\% blue light and 70\% red light" applications (4.6). As a result, wavelengths of light have significant effects on plant heights, root lengths and the number of root of stevia.

\section{Conclusions}

Electrical artificial light sources are generally used for irradiation of plants in order to provide PAR (effective radiation in photosynthesis) energy when the natural light is

Table 1. The effects of lighting applications in wavelength on morphological and physiological properties of stevia plant

\begin{tabular}{|c|c|c|c|c|c|c|c|}
\hline \multirow[b]{2}{*}{ Applications } & \multicolumn{7}{|c|}{ Test index } \\
\hline & $\mathrm{L}^{* *}$ & $a^{* *}$ & $b^{*}$ & $\begin{array}{c}\text { Chlorophyll } \\
\text { content }^{*}\end{array}$ & Plant height* & Root height* & Root number** \\
\hline $\mathrm{T} 1$ & $44.22 \mathrm{a}$ & $-18.51 \mathrm{a}$ & $23.88 \mathrm{ab}$ & $39.08 \mathrm{a}$ & $8.04 b$ & $16.44 a$ & $4.6 \mathrm{~b}$ \\
\hline $\mathrm{T} 2$ & $44.50 \mathrm{a}$ & $-15.48 b$ & $21.40 \mathrm{~b}$ & $36.05 \mathrm{ba}$ & $9.04 b$ & $15.56 \mathrm{ba}$ & $7.8 \mathrm{a}$ \\
\hline T3 & $40.341 b$ & $-16.26 b$ & $23.23 \mathrm{ab}$ & $35.92 \mathrm{ba}$ & $13.6 \mathrm{a}$ & $14.00 \mathrm{bc}$ & $4.6 \mathrm{~b}$ \\
\hline $\mathrm{T} 4$ & $43.5 \mathrm{a}$ & $-15.46 b$ & $24.77 a$ & $32.44 b$ & $9.20 \mathrm{~b}$ & $13.20 \mathrm{c}$ & $6.4 \mathrm{ba}$ \\
\hline
\end{tabular}

In lines and columns, according to Duncan Test at the level of $\mathrm{P} \leq 0.05$ different environments were denoted with different letter. (According to * 0.05 , according to ${ }^{* *} 0.01$ statistically significant) (" $50 \%$ blue $+50 \%$ red", "70\% blue+ $30 \%$ red", " $30 \%$ blue $+70 \%$ red", daylight) 
358

not sufficient. One color wavelength of light application could be performed by using LED lamps on herbal production and plants can be irradiated with wavelengths of light in blue and red regions. Thusly, artificial irradiation possibilities are provided in wavelengths (colors) that are suitable for plants need for photosynthesis. The growth ratios of plants under various wavelengths of light show differences depending on the species of plants, therefore the yield of a plant can be increased under various wavelengths of light. As a result of study, the chlorophyll amounts of leaf, the leaf color values $(\mathrm{L}, a, b)$, the plant heights, the root lengths and the number of root of stevia demonstrate the differences depending on the applications of different wavelengths of light. So, while the highest plant height was determined in the " $30 \%$ blue light $+70 \%$ red light" application, the highest stem length was found in the " $50 \%$ blue light $+50 \%$ red light" application. The number of the stem reached the highest value in the " $70 \%$ blue light $+30 \%$ red light" application. Consequently, a correlation was observed between negative " $a$ " value and amount of chlorophyll. Finally, comparing to other applications, the "50\% blue light $+50 \%$ red light" was found as the best light application to obtain optimum yield values of stevia.

\section{References}

Anonim(2015).http://mebk12.meb.gov.tr/meb_iys_dosyalar/16/0 5/964258/dosyalar/2013_12/04104609_bitkilerdebeslenmeby mevehareket.pdf.

Argueta VA, Cano AL (1993). El Atlas de las plantas de la medicina tradicional Mexicana. [Atlas of traditional medicinal plants of Mexico]. Mexico: Instituto Nacional Indigenista 1786.

Aybak HÇ (2002). BiberYetiştiriciliği. HasadYayıncllkk, Istanbul, 157 ss.

Brazaityte A, Duchovskis P, Urbonaviciüte A, Samuoliene G, Jankauskiene J, Sakalauskaite J, Sabajeviene G, Sirtautas R, Novickovas A (2010). The effect of light-emitting diodes lightingon the growth of tomato transplants. ZemdirbysteAgriculture 97(2):89-98.

Carneiro JWP, Muniz AS, Guedes TA (1997). Greenhouse bedding plant production of Stevia rebaudiana (Bert) Bertoni. Canadian Journal of Plant Science 77:473-474.

Cerda-García-Rojas CM, Pereda-Miranda R (2002). The phytochemistry of Stevia: a general survey. In: Kinghorn D (Ed), The genus Stevia. Taylor \& Francis, New York pp 86-118.

Cimpeanu M, Toma I, Zbughin G, Cimpeanu C, Capraru G (2006). Cytogenetics and morpho-anatomy in Stevia rebaudiana Berton. Proceedings from the Third Conference on Medicinal and Aromatic Plants of Southeast European Countries (Proceedings from the 3rd CMAPSEEC). Belgrade, Serbia pp 108-112.

Çağlayan N, Ertekin C (2011). Bitkisel Üretim İçin LED Yetiştirme Lambalarnın Kullanımı. Uluslararası Katılımlı I. Ali Numan Kıraç Tarım Kongresi ve Fuarı 1227-1232.

Demirtaş MN, Kurnak H (2009). Kayısıda Farklı Sulama Yöntemleri ve Aralklarnnn Fizyolojik Parametrelere Etkisi. Yüzüncü Yıl Üniversitesi Tarım Bilimleri Dergisi (YYU J AgrScI) 19(2):79-83.
Freed RD (1988). MSTAT-C. Michigan State University. Crop and Soil Science Version 2.10.

Fronza D, Folegatti MV (2003). Water consumption of the Stevia (Stevia rebaudiana [Bert.] Bertoni) crop estimated through micro-lysimeter. Scientia Agricola 60:595-599.

Furuya M (1993). Phytochromes: their molecular species, gene families and functions. Annual Review of Plant Physiology 44:617-645.

Heuvelink E (1989). Influence of day and night temperature on the growth of young tomato plants. Scientia Horticulturae 38:11-22.

İnanç AL, Çınar İ (2009). Alternatif Doğal Tatlandıııı: Stevya. Gıda $34(6): 411-415$.

Jao RC, Fang W (2003). An adjustable light source for photo-phyto related research and young plant production. Applied Engineering in Agriculture 19(5):601-608.

Jao RC, Fang W (2004). Growth of potato plantlets in vitro is different when provided concurrent versus alternating red and blue light photoperiods. HortScience 39(2):380-382.

Jao RC, Lai CC, Fang W, Chang SF (2005). Effects of red light on the growth of Zantedeschia plantlets in vitro and tuber formation using light-emitting diodes. HortScience 40(2):436-438.

Kevseroğlu K (1999). Bitki Ekolojisi. O.M.Ü. Ziraat Fakültesi Ders Kitabı No:31, Samsun.

Koç C, Vatandaş M, Koç AB (2009). LED aydınlatma teknolojisi ve Tarımda Kullanımı. 25. Tarımsal Mekanizasyon Ulusal Kongresi 153-158.

Matsuda R, Ohashi-Kaneko K, Fujiwara K, Goto E, Kurata K (2004). Photosynthetic characteristics of rice leaves grown under red light with or without supplemental blue light. Plant and Cell Physiology 45(12):1870-1874.

McCree KJ (1972). Test of current definitions of photosynthetically active radiation against the leaf photosynthesis data. Agricultural and Forest Meteorology 10:443-453.

McGuire RG (1992). Reporting of objective color measurements. HortScience 27:1254-1255.

Megeji NW, Kumar JK, Singh V, Kaul VK, Ahuja PS (2005). Introducing Stevia rebaudiana, a natural zero-calorie sweetener. Current Science 88(5):801-804.

Nhut DT, Nam NB (2010). Light-emitting diodes (LEDs): An artificial lighting source for biological studies. Proceedings of the 3rd International Conference on the Development of BME in Vietnam, pp 133-138.

Okawa M, Kinjo J, Nohara T, Ono M (2001). DPPH (1,1-diphenyl2-picrylhydrazyl) radical scavenging activity of flavonoids obtained from some medicinal plants. Biological and Pharmaceutical Bulletin 24:1202-1205.

Öztürk HH (2008). Sera İklimlendirmeTekniği. Hasad Yayıncllk Ltd. Şti 267-269. İstanbul.

Piszczek P, Glowacka B (2008). Effect of the colour of light on cucumber (Cucumss sativus L.) seedlings. Vegetable Crops Research Bulletin 68:71-80.

Spalding EP, Folta KM (2005). Illuminating topics in plant photobiology. Plant, Cell and Environment 28(1):39-53.

Saebo A, Krekling T, Applegren M (1995). Light quality affects 
photosynthesis and leaf anatomy of birch plantlets in vitro. Plant, Cell, Tissue and Organ Culture 41(2):177-185.

Seeman J (1952). Strahlungs verhaltnisse in Gewachshausern. Arhicfür Metorologie. Geophys. U. Bioklim. Serie band IV.

Sevgican A, Tüzel Y, Gül A, Eltez RZ (2000). Türkiye'de örtü altı yetiştiriciliği. Türkiye Ziraat Mühendisleri V. TeknikKongresi 2: 679-707.

Singh SD, Rao GP (2005). Stevia: The herbal sugar of 21st century. Sugar Technology 7(l):17-24.

Shock CC (1982). Experimental cultivation of Rebaudi's stevia in California. University of California, Davis, Agronomy Progress Rep. 122.

Tripathy BC, Brown CS (1995) Root-shoot interaction in the greening of wheat seedlings grown under red light. Plant Physiology 107:407-411.

Wu CC, Hsu ST, Chang MY, Fang W (2011). Effect of light environment on runner plant propagation of strawberry. In: VI International Symposium on Light in Horticulture 907:297-302.
Urbonaviciute A, Pinho P, Samuoliene G, Duchovskis P, Vitta P, Stonkus A, Tamulaitis G, Zukauskas A, Halonen L (2007). Effect of short-wavelength light on lettuce growth and nutrotional quality. Scientific Works of the Lithuanian Institute of Horticulture and Lithuanian University of Agriculture Sodininkyst Ir Daržininkyst 26:157-165.

Uzun S (1996). The quantitative effects of temperature and light environment on the growth, development and yield of tomato and aubergine (Unpublished $\mathrm{PhD}$ Thesis). The University of Reading, England.

Vardar Y (1975). Bitki Fizyolojisine Giriş. Ticaret Gazetesi Matbaası, İzmir 229 ss.

Yadav AK, Singh S, Dhyani D, Ahuj PS (2011). A review on the improvement of stevia [Stevia rebaudiana (Bertoni)]. Canadian Journal of Plant Science 91(1):1-27.

Yağcıoğlu A (1996). TarımsalElektrifikasyon (Genişletilmiş 2. Basım). EÜZF Yayınları No:488. 